\title{
Do foreign banks intensify borrower discouragement? The role of developed European institutions in ameliorating SME financing constraints
}

\author{
Ana Mol-Gómez-Vázquez ${ }^{1 *}$, Ginés Hernández-Cánovas² ${ }^{2}$ Johanna Koëter-Kant ${ }^{3}$ \\ 1* Universidad de Alicante, Department of Financial Economics and Accounting, Carretera de San Vicente \\ del Raspeig, s/n, 03690 San Vicente del Raspeig, Alicante, Spain. E-mail: ana.mol@ua.es \\ ${ }^{2}$ Universidad Politécnica de Cartagena, Faculty of Business Administration, C/ Real nº3, 30201 Cartagena, \\ Spain. E-mail: gines.hernandez@upct.es \\ ${ }^{3}$ Vrije Universiteit Amsterdam, Faculty of Economics and Business Administration, De Boelelaan 1105 \\ 1A-37, 1081 HV Amsterdam, the Netherlands. E-mail: jkoeter@feweb.vu.nl \\ * Corresponding author
}

\begin{abstract}
The growing activity of foreign banks in most European countries may increase firms' financing constraints by intensifying the problem of borrower discouragement. We provide new evidence on this association by analysing a sample of small and medium-sized enterprises (SMEs) operating in 25 developed and developing European countries. We find that financing constraints deeply increase with foreign banks for those SMEs operating in countries where the share of banking assets owned by foreign banks is above 34\%. Our results also show that borrower discouragement may decrease (or increase less) with the presence of foreign banks for SMEs operating in countries with high income, with cheap debt enforcement mechanisms, or having a private bureau that provides credit information about firms and individuals. These results suggest that the unification towards better institutions shall take place in Europe before the banking union continues to a more open banking system.
\end{abstract}

Keywords: borrower discouragement, foreign banks, small business lending, institutional development, financing constraints.

Acknowledgements: Ana Mol-Gómez-Vázquez and Ginés Hernández-Cánovas acknowledge financial support by Santander Financial Institute (SANFI) and Fundación UCEIF.

\section{Post-print version}

Mol-Gómez-Vázquez, A., Hernández-Cánovas, G., \& Koëter-Kant, J. (2020). Do foreign banks intensify borrower discouragement? The role of developed European institutions in ameliorating SME financing constraints, International Small

Business Journal: Researching Entrepreneurship, 38(1), pp. 3-20.

(doi.org/10.1177/0266242619868231) 


\section{Introduction}

The process of liberalisation of the European financial markets has been influential in changing the structure of the banking system (Padoa-Schioppa, 2004). Data obtained from the World Bank shows that the presence of foreign banks in most EU 28 has increased from 1995 to 2014, with Eastern European countries such as Estonia (from 8\% to $75 \%$ ), Croatia (from $6 \%$ to $52 \%$ ), and Lithuania (from $0 \%$ to $75 \%$ ) experiencing the highest increase. In addition, this process is likely to continue in the future, as the ECB recognises that completing the banking union is not a long-term project because "leaving the banking union unfinished would be the opposite of risk reduction...We need a deeply integrated financial system with well-capitalised intermediaries that are active across borders and benefit from the risk diversification options that the economic diversity of the euro area offers” (Praet, 2016). However, a higher presence of foreign banks may increase financial constraints for SMEs. The aim of this article is to shed additional light on this problem by examining the association between the presence of foreign banks in a country and borrower discouragement for SMEs, and how this relationship might be affected by the strength of a country's institutions.

The presence of foreign banks may bring benefits to a country's banking system by introducing new skills, facilitating the access of firms to international capital markets and increasing competition in the market for large companies. However, from the theoretical point of view we may expect a less positive effect of foreign banks on smaller firms, and varying effects across firms operating in different institutional environments. These variations are likely to arise because informational asymmetries influence the borrowerlender relationship and, therefore, the demand and access to debt financing. This is especially true for the relationship between foreign banks and SMEs. On the one hand, foreign banks usually have a disadvantage in granting relationship lending to opaque and 
risky firms because they have less access to soft information or they are either less willing or less able to process it along their hierarchical organisational structures. On the other hand, SMEs are characterised by high informational asymmetries and lack of assets to pledge as guarantees that could reduce their risk (Hanedar, Broccardo and Bazzana, 2014). Consequently, we analyse whether the liberalisation of the banking system affects the access of SMEs to debt financing through changes in the presence of foreign banks, and whether the strength of a country's institutions produces different results across countries. We do that using a survey data set of 2,582 firms operating in 25 developed and developing European countries.

Our article contributes to the literature in several ways. Firstly, we analyse if the share of foreign banks in a country's banking sector influences firms' financing constraints. We do so by analysing the intensity of discouraged borrowers, who are quality firms that choose not to apply for the financing they need (Kon and Storey, 2003). This form of financial restrictions is more frequent than credit denial (Levenson and Willard, 2000), and has an economic impact twice the size of rejected borrowers ${ }^{1}$. Secondly, we also contribute by allowing for a greater flexibility in the estimation of our model in order to identify a heterogeneous relationship between foreign banks and borrower discouragement. Existing literature suggests that positive and negative effects of foreign banks may coexist, but they would dominate at different ranges of foreign banks penetration in a country (Cull and Pería, 2008; Gormley, 2011; Claessens and van Horen, 2014). Using a zero-truncated Poisson count model, our results show that a higher presence of foreign banks in a country reduces the intensity of borrower discouragement when their share of assets in the banking sector is below 34\%, point at which foreign banks turn to have a detrimental effect on SMEs access to debt. Moreover, acknowledging 
that we do not have the ideal risk measures, we are able to show that more intensely discouraged borrowers are not riskier firms.

Finally, we also allow for the possibility that the effect of foreign banks on borrower discouragement could be moderated by the strength of a country's institutions. Informational asymmetries are lower in more developed economies (Claessens and Laeven, 2004), which is likely to influence the association between foreign banks and borrower discouragement. Our results show that a higher presence of foreign banks produces a lower increase in the intensity of borrower discouragement for firms operating in countries with high income, with low cost of enforcing debt contracts, or having an information infrastructure. These differences in the level of institutional development also explain why borrower discouragement in our sample appears to be higher for SMEs operating in the 10 newer Member States (EU 10) compared to the 15 old Member States (EU 15) of the European Union. These results could help to understand why previous studies find that the overall size of the banking sector of developing countries decreases with the presence of foreign banks, even if these credit institutions aim at offering loans to SMEs (Detragiache, Tressel and Gupta, 2008; Claesssens and van Horen, 2014).

The rest of the article is organised as follows. First we discuss previous literature and develop the hypotheses. After that we present the variables, data and methodology, followed by the results. Finally, we present the summary and conclusions.

\section{Theory and hypothesis development}

The liberalisation of the European financial landscape has facilitated the development of cross-border activity (Padoa-Schioppa, 2004). However, changing the structure of a country's banking sector influences the flow and use of soft information (Berger, Demirgüç-Kunt, Levine and Haubrich, 2004) which, in turn, might exacerbate the 
problem of borrower discouragement for SMEs. Soft information has a key role in lending to SMEs because the scale and scope of hard information are usually limited (Grunert and Norden, 2012).

According to Kon and Storey (2003), imperfect information is the primary source of discouraged borrowers, who are good (quality) firms that choose not to apply for a loan due to bank's screening error, the existence of application costs and the availability of alternative funding from moneylenders. Therefore, the existence of discouraged borrowers reflects a market failure because quality firms choose not to apply for bank funding even though they are in need of financing. We expect a non-linear relationship between the presence of foreign banks in a country and borrower discouragement. We argue that the level of foreign bank penetration per se is likely to change the marginal effect that foreign banks have on the balance among screening errors, the scale of application costs and the extent to which interest rate differs from that charged by moneylenders.

On the one hand, foreign banks with a low presence in a country may incur in high screening errors because their availability of soft information about SMEs is scarce. But, at the same time, poorly informed foreign banks impose low costs to applicants because any requirement for additional information can be easily met (Kon and Storey, 2003). In addition, the relative cost of loan applications could decrease with the initial presence of foreign banks offering better skills and services, diversification of risks, and access to international capital markets (Berger, DeYoung, Genay and Udell, 2000). As for the interest rate charged to SMEs, the gap between banks and moneylenders is likely to increase with the initial presence of foreign banks if domestic banks increase their focus on SMEs. According to the cherry pick effect (Degryse, Havrylchyk, Jurzyk and Kozak, 2012), foreign banks grant most of their credit to more transparent and less risky firms 
because they are less suitable to provide relationship lending to SMEs (Berger and Udell, 2006). By cherry-picking, foreign banks increase the competition in the market for large companies and force domestic banks (see segregation effect in Dell'Ariccia and Marquez, 2004) to increase the share of SMEs in their portfolios. Therefore, we expect that borrower discouragement decreases with the initial presence of foreign banks in a country if lower costs of loan applications and higher cost of alternative funding compensate for higher screening errors

On the other hand, foreign banks with a high presence in a country may achieve more autonomy and deeper knowledge about SMEs, which eventually may result in lower screening errors. However, soft information is difficult to transmit in the large and hierarchical structures of foreign banks, which are headquartered at a considerable distance from small and local businesses, and used to operate in a different economic, institutional and cultural environment (Berger, Klapper and Udell, 2001; Jiménez, Salas and Saurina, 2009). This is supported by Beck, Demirgüç-Kunt and Pería (2011) showing that foreign banks do not rate soft information as an important factor in evaluating loans. Therefore, there is a high probability that foreign banks continue cherry picking large and transparent companies after reaching an important presence in a country. This will leave an increasing percentage of good SMEs going to the moneylender market, which reduces the extent to which the bank interest rate differs from that charged by the moneylender. Finally, the cost that foreign banks impose upon applicants is expected to rise because firms have more difficulties in fulfilling the information requirements of better informed banks (Kon and Storey, 2003). Therefore, we expect that, at some point, borrower discouragement increases with the presence of foreign banks if higher application costs and lower cost of alternative funding overcome lower screening errors.

Based on the above arguments our first hypothesis is as follows: 
Hypothesis 1. The association between the presence of foreign banks and the intensity of borrower discouragement for SMEs follows a U-shape.

Up to the best of our knowledge there are not previous studies on the association between borrower discouragement and foreign banks. Related works suggest that there could be a non-monotonic association between foreign banks and borrower discouragement due to the existence of differences in the level of development of the institutional environment. Theoretical models in Boustanifar (2014) and Gormley (2014) show that the strength of a country's institutions is important in determining the effect that foreign lenders may have in a country's economy and financial sector. There are also studies that find a reduction in the amount of bank credit to the private sector (as a percentage of GDP) as a consequence of a higher presence of foreign banks in lowincome countries, whereas this effect disappears for developed countries (Detragiache et al., 2008; Gormley, 2014). The underlying argument is that rich economies and strong institutions may ameliorate informational asymmetries and reduce screening costs (Claessens and Laeven, 2004), making SMEs lending more feasible or desirable for foreign banks. This would mean that borrower discouragement is determined by a combination of foreign bank presence and institutional development. Following this argument, our second hypothesis is as follows:

Hypothesis 2. The existence of more developed institutions ameliorates the intensity of discouragement that SMEs could experience due to the increased presence of foreign banks. 


\section{Data and method}

\section{Dependent variable}

We consider discouraged borrowers to be those firms which have not applied for a loan but would have been encouraged to resort to a loan if one or several of the following factors had been more advantageous: (1) interest rates; (2) procedures for granting loans; (3) guarantee requirements; (4) delays in granting loans; (5) other reasons. Using these answers from the survey question, we build the variable discouraged counting (adding) each one of the reasons that would have encouraged firms to apply for a loan. Therefore the variable discouraged proxies for the intensity of borrower discouragement ranging from 1 to 5, where higher scores indicate higher discouragement intensity ${ }^{2}$.

The so-called ideal comparison, undertaken in previous research, would be between applicants and non-applicants, taking account of a range of risk factors, and then analysing how the presence of foreign banks influences that relationship. However, going beyond this traditional approach, we follow Mol-Gómez-Vázquez, Hernández-Cánovas and Koëter-Kant (2018b) and only focus on those borrowers who are discouraged, analysing whether the presence of foreign banks intensifies or ameliorates the magnitude of their discouragement ${ }^{3}$. The argument for this approach is that the more reasons discouraged borrowers have for their behaviour, the more complicated the solution to their discouragement will be. This is especially important in light of the statistics shown in Table 1, where we observe the existence of a large variation in the intensity of borrower discouragement. For example, in 13 out of 25 countries in our sample, more than $50 \%$ of firms experience what we call multiple discouragement, which are firms having two or more reasons for being discouraged from applying for a loan. Overall our sample contains 1,219 SMEs (47.21\% of the observations) suffering multiple discouragement. 


\section{Independent variables}

This section describes the explanatory variables used in our empirical study. Table 2 provides detailed definitions of all the variables.

\section{[Insert Table 2]}

Foreign bank presence. We measure the presence of foreign banks in a country banking system using the variable foreign. This variable equals the share of the banking system assets that are owned by foreign banks. Higher values for the variable foreign indicate the existence of a wider and stronger participation of foreign banks in the banking system of a country. This measure has been widely used in the financial literature (Claessens and Laeven, 2004; Clarke, Cull and Pería, 2006; Claessens and van Horen, 2014).

Table 1 shows large variations across countries in the participation of foreign banks in the banking system, from Germany with a $4.21 \%$ of banking assets held by foreign banks, to Lithuania with a $91.31 \%$. Dividing the countries in two groups according to the mean value of the variable foreign, we can also observe that 11 out of the 12 countries with low presence of foreign banks belong to the EU 15, while 9 out of the 13 countries with high presence of foreign banks belong to the EU 10. Finally, Table 1 contains mean comparison tests between firms in both groups, which are statistically significant at the 1\% level. Results indicate, for example, that firms in countries with high presence of foreign banks are more intensely discouraged (2.48) and more commonly affected by multiple discouragement (65.45\%) than firms in countries with low presence of foreign banks (1.70 and $36.45 \%$ respectively).

Country-specific variables. We include a set of country factors to control for additional heterogeneity across European countries. By influencing the willingness to establish close banking relationships, the market power of banks may affect the problem of borrower 
discouragement (Mol-Gómez-Vázquez et al., 2018b). Following previous financial literature (Claessens and Laeven, 2004; Cole and Sokolyk, 2016) we control for bank market power using a measure of concentration, the Herfindahl-Hirschman index. As the Herfindahl variable increases, the market power of banks increases. Previous evidence also shows that borrower discouragement decreases with the existence of better institutions (Chakravarty and Xiang, 2013; Mac and Bhaird, Vidal and Lucey, 2016). We include the variables GDP per capita and GDP growth to control for the level of economic development and the growth rate of the economy, the variables enforcement and recovery to measure the efficiency of the legal environment when enforcing debt contracts and dealing with credit recovery after bankruptcy, and the variable information to control for the existence of an information infrastructure in a country.

Table 3 shows the existence of large differences across countries in the level of concentration of the banking sector and the strength of institutions, and how they are related with the level of economic development. It is shown that rich and poor countries may differ in aspects such as the recovery rate, which has an average value of 0.7847 for the high income countries and 0.4754 for the low income countries, or the level of concentration of the banking system, which achieves an average value of 0.1082 for the high income countries and 0.1569 for the low income countries ${ }^{4}$. However, it also happens that for other characteristics of the institutional environment such as the cost of enforcing debt contracts, the mean values for high (0.1127) and low income $(0.1101)$ countries are quite similar.

\section{[Insert Table 3]}

Firm-specific variables ${ }^{5}$. The firm-specific variables size, age, constraint and relation have been included in order to control for firm heterogeneity in our sample. Due to the existence of longer track records, wider public presence, and larger availability of assets 
to pledge as collateral, larger and older firms are expected to suffer less from borrower discouragement (Chakravarty and Xiang, 2013; Xiang, Worthington and Higgs, 2015; Mac an Bhaird et al., 2016). We also take into account that borrower discouragement may decrease if firms' managers have a better perception about their credit situation (Mac an Bhaird et al., 2016), i.e., perceiving less financing constraints or the existence of a better relationship with their banks. Finally, we control for differences across industries in the amount of fixed assets, which is likely to influence discouraged borrowers (Freel, Carter, Tagg and Mason, 2012), creating seven industry dummies ${ }^{6}$.

\section{Methodology and data}

Due to the discrete and non-negative count nature of the dependent variable discouraged, we estimate a zero-truncated Poisson count model regression to analyse how the intensity of borrower discouragement is influenced by the presence of foreign banks ${ }^{7}$. The model presents the following form:

$$
\text { discouraged }_{i=\alpha_{0}}+\beta_{1} \text { foreign }_{i}+\beta_{2} \text { foreign }_{i * \text { foreign }_{i}}+\beta_{3} \text { CSC }_{i}+\beta_{4} \mathrm{FSC}_{i}+\varepsilon_{i}
$$

Where $i$ represents the $i^{\text {th }}$ firm in the sample; discouraged $i$ is the dependent variable for the firm $i$; foreign $_{i}$ is our main variable measuring the presence of foreign banks in a country's banking system; $C S C_{i}$ is the vector of country-specific control variables; $F S C_{i}$ represents the set of firm-specific control variables, and $\varepsilon_{i}$ is the residual ${ }^{8}$.

Our sample is based on the Flash Eurobarometer Survey on SME Access to Finance carried out by the European Commission between 2005 and 2006. From this survey we obtain the data regarding borrower discouragement and the remaining firm-specific variables for 4,583 SMEs in the EU 25. Unfortunately, the period used in this article is limited by data availability. Therefore, we cannot take into consideration a longer period or attempt to implement the analysis with more current data. However, our empirical 
contribution, previous to the financial crisis, will allow future contributions to compare the impact of foreign banks on discouraged SMEs across different economic and financial scenarios. Moreover, this survey data set has been used in articles recently published in reference journals (Canton, Grilo, Monteagudo and Van der Zwan, 2013; Mol-GómezVázquez, Hernández-Cánovas and Koëter-Kant, 2018a, 2018b).

In our sample, 3,047 firms (66\%) belong to the EU 15 and the remaining 1,536 firms (34\%) belong to the EU 10 (Bulgaria, Romania and Croatia are not represented because they joined the European Union after 2006). Interviews were conducted in September 2005 in the EU 15 and between April and May 2006 in the EU 10. After dropping 125 firms operating in the financial sector, we keep 2,582 observations which contain information about borrower discouragement ${ }^{9}$. Finally we lose 526 observations due to missing values in one or several of the independent variables, arriving to a final sample for our regressions made up of 2,056 observations from 22 countries (14 old Member States and 8 new Member States). Variables describing the presence of foreign banks and country-specific variables are obtained from Micco, Panizza and Yañez (2004), the European Central Bank, the United Nations Statistics Division, and Doing Business Indicators. Table 4 reports the correlations, where no collinearity problems are detected.

\section{[Insert Table 4]}

\section{[Insert Table 5]}

Table 5 shows a summary of statistic for the variables used in our regressions. The first thing we notice is that the variable size shows a mean value of around 3, which in our categorical classification places the average observation in our sample into the group of micro firms, with an annual turnover bellow two million Euros. This is important because most empirical research in the financial literature neglects this group of firms due to the lack of data. In spite of their reduced dimension, managers have a moderate 
perception about the existence of financial constraints (2.4589) and the strength of their banking relationships (1.9917). As for the institutional environment, enforcing debt contracts has an average cost of $11.96 \%$ and ranges from a minimum of $5.9 \%$ to a maximum of $21.1 \%$, the recovery rate from insolvent firms ranges from 16.8 to 90.2 cents on a dollar with a mean value of 60.59 , and around $25 \%$ of firms operate in countries without private credit registries about firms and individuals. These numbers show that European countries still have an important task in trying to improve the strength and efficiency of their institutions.

\section{Results}

Table 6, Column 1, contains the non-linear specification, which includes the quadratic term of the variable foreign, aimed at testing our first hypothesis. The coefficients for the variables foreign and foreign*foreign are statistically significant (at the $1 \%$ level), with a negative and positive sign respectively. This confirms hypothesis 1 , indicating that the association between the presence of foreign banks in a country and the intensity of borrower discouragement follows a U-shape. The minimum of this relationship is achieved when foreign banks own $34.04 \%$ of the banking system assets, which is around the $75^{\text {th }}$ percentile for the variable foreign. This means that around $25 \%$ of firms in our sample are, compared to the remaining $75 \%$, more discouraged from applying for a loan as the presence of foreign banks in the banking sector increases. Even if the number of firms being harmed by the presence of foreign banks is smaller than those that are benefited, the economic impact of the former is much more significant. The intensity of borrower discouragement increases around $170 \%$ (from 1.23 to 3.3) if the variable foreign increases from a value of $34.04 \%$ (where the U-shape reaches its minimum) to $91.31 \%$ (the sample maximum), whereas it decreases less than 25\% (from 1.60 to 1.23) if the 
share of assets owned by foreign banks goes from $4.21 \%$ (the sample minimum) to $34.04 \%$.

Next, in Columns 2-4, Table 6, we introduce the interaction terms of the variable foreign with the variables GDP per capita, enforcement and information respectively. We do this to test, in our second hypothesis, whether the effect of foreign banks on borrower discouragement depends on the development of a country's institutions ${ }^{10}$. The coefficients for the three interaction terms are statistically significant (at the $1 \%$ level), confirming hypothesis 2 . The negative sign for the coefficients on the variables foreign*GDP per capita and foreign*information and the positive sign for the coefficient on the variable foreign*enforcement indicate that better institutions can mitigate the harmful effect that foreign banks have on discouraged borrowers ${ }^{11}$. This also means that borrower discouragement may decrease (or increase less) with the presence of foreign banks in countries with high income, with cheap debt enforcement mechanisms, or having a private bureau providing credit information about firms and individuals. For example, for firms operating in the country with the most expensive (cheapest) debt enforcement mechanism, a one standard deviation increase in the variable foreign induces an increase of $52.04 \%$ (decrease $14.55 \%$ ) in the intensity of borrower discouragement. The same variation in the variable foreign originates that the intensity of borrower discouragement decreases $12.17 \%$ (increases $43.01 \%$ ) for firms operating in the richest (poorest) country in our sample.

However, we cannot fully rule out that the non-monotonic association between foreign banks and borrower discouragement is also due to the degree of presence of foreign banks per se. In Columns 2-4, Table 6, we also obtain the U-shaped relationship between borrower discouragement and foreign banks. The coefficient on the variable foreign*foreign remains positive and statistically significant, while the coefficient on the 
variable foreign becomes negative for those firms operating in countries with better institutions. As a consequence, we believe that the level of institutional development and the share of foreign banks in the banking system are both important in explaining the influence of foreign banks on borrower discouragement.

Regarding the control variables, results across the different specifications of Table 6 remain consistent with the existing literature (Freel et al., 2012; Leon, 2015; Xiang et al., 2015; Mac an Bhaird et al. 2016). Borrowers operating in more developed countries or in economies which are growing at a higher rate are subject to lower levels of discouragement. Our results also show that a more efficient legal environment when dealing with bankruptcy procedures helps to reduced borrower discouragement. We find that the existence of a private registry that provides information about individuals and firms also proves to be important in ameliorating the problem of discouraged borrowers. As for the firm-specific variables, our results seem to suggest that borrower discouragement is associated with the existence of informational asymmetries. We find that borrowers of smaller size or having a worse relationship with their bank are more discouraged.

\section{[Insert Table 6]}

\section{Robustness checks}

One limitation of our dependent variable is that there is not distinction between good and bad borrowers. So, one could wonder whether more intensely discouraged borrowers are actually riskier or worse firms and, therefore, discouragement would be seen as desirable. Unfortunately our data set does not provide detailed financial information in order to make a comprehensive assessment of the quality of borrowers and its association with their discouraged level. We can only create three dummy variables that take the value one 
if the firm's manager recognises that the situation of the firm has deteriorated since the last year in terms of turnover, profit margin and cash flow respectively and zero otherwise. Using these risk indicators we try to address this issue empirically following Ferrando and Mulier (2015) $)^{12}$.

Firstly, Table 7 contains a one-way analysis of variance (ANOVA) that tests for differences in the variables turnover, profit margin and cash flow broken down by the levels of the variable discouraged. We observe that profit margin is the only variable where the mean differs significantly among the levels of borrower discouragement. However, in unreported results (available upon request), Bonferroni, Scheffe and Sidak multiple comparison tests indicate that the differences between the means of these variables for each pair of discouragement levels are not statistically significant.

\section{[Insert Table 7]}

Secondly, to find out whether borrowers subject to more intense discouragement are riskier over and above the other factors that drive discouragement, we regress in the following empirical model (2) our risk indicators on basically the same model as in our base model (1) and add the variable discouraged as independent variable:

risk $_{i}=\alpha_{0}+\beta_{1}$ discouraged $_{i}+\beta_{2}$ foreign $_{i}+\beta_{3}$ foreign $_{i}{ }^{*}$ foreign $_{i}+\beta_{4}$ CSC $_{i}+\beta_{5}$ FSC $_{i}+\varepsilon_{i}(2)$

Where risk measures are the dummy variables turnover, profit margin and cash flow. For the sake of conciseness and brevity, in Column 5, Table 6, we only report the regression results using the dependent variable that is significant in Table 7, profit margin (results using the other dependent variables remain qualitative the same). We find that the coefficient on the variable discouraged is not statistically significant, indicating that borrowers subject to more intense discouragement are not more likely to have their profit margin deteriorated since the last year. Thirdly, in unreported regressions (available upon request) we find that our results remain qualitative the same if we run Columns 1-4, Table 
6 , on the subset of firms that did not have their profit margin, turn over or cash flow deteriorated since the last year. In light of the above analyses, in our sample we strongly believe that more intensely discouraged borrowers are not riskier firms.

One could also wonder whether our results are driven by the influence of a single reason such as interest rates or guarantees on the variable discouraged. To check this possibility, we create five alternative definitions of our dependent variable excluding from each counting one of the reasons for borrower discouragement. The five new dependent variables, which now range from 1 to 4, enable us to re-estimate Columns 1-4 in Table 6 five times, thus originating 20 new regressions. The only change in our results is shown in Column 6, Table 6, where the variable foreign*GDP per capita becomes statistically insignificant when interest rate is not taken into account to build the dependent variable. To check the robustness of this result, we follow endnote 10 and substitute the variable GDP per capita by a dummy variable that equals one if the country's GDP per capita is above the sample mean and zero otherwise. In unreported regression (available upon request) we find that firms operating in richer countries suffer less intense discouragement when the presence of foreign banks increases. This confirms that our main results hold even if we do not count the interest rate reason to build our dependent variable. The above analyses strongly reject the argument that our results are explained by the impact of any single reason on the variable discouraged.

\section{Summary and conclusion}

The ongoing and significant process of foreign direct investment in the European banking system, which began two decades ago, continues raising the concerns of policy makers, professionals and academics. The efficiency and international dimension of foreign banks will likely bring benefits for large and transparent companies, while the role of foreign 
banks in SME financing constraints remains unclear. Existing empirical evidence is missed and has largely neglected the demand-side perspective. Besides being rationed, SMEs can suffer financing constraints if they are discouraged from applying for the debt resources they need for their investments.

Extended borrower discouragement could explain, for example, why a higher presence of foreign banks leads to an overall reduction in the amount of credit being granted to the private sector in countries where foreign banks seem to target the market for SMEs. In addition, differences in foreign bank presence and borrower discouragement intensity across countries call for an international analysis of this question. This article provides new insights into this problem analysing the association between borrower discouragement and foreign banks using a sample of SMEs from 25 European countries.

We find that the existence of large differences in the presence of foreign banks in European countries is responsible for the variations in the intensity of discouraged borrowers across European SMEs. Borrower discouragement increases with the presence of foreign banks for firms in countries where more than 34\% of the banking system assets are held by foreign banks. This means that once foreign banks control more than one third of the banking system assets, increasing their presence in a country becomes a detrimental aspect of the credit market that intensifies the level of discouraged borrowers. However, the association between foreign banks and borrower discouragement is moderated, to a large extent, by the strength of a country’s institutions. More developed economies, cheaper debt enforcement mechanisms and better private information registries in a country could significantly ameliorate borrower discouragement resulting from a higher presence of foreign banks.

Our study contains evidence with clear implications for firms, financial institutions, policy makers, and academics. Firstly, firms should be aware of the ongoing 
transformation of the banking system triggered by the financial liberalisation. The presence of foreign banks could result in a decline in lending to the most vulnerable firms, which are those of reduced dimension operating in less developed economies. Secondly, the flow of credit towards SMEs should be a concern for foreign banks, which should be aware of problems such as borrower discouragement limiting the demand for credit. Thirdly, policy makers should take into account the disadvantageous consequences that our results reveal for the financing of SMEs and, therefore, their growth and survival. Growing financial liberalisation leading to increased penetration of foreign banks may result in more discouraged and constrained SMEs, which hampers job creation and economic growth. Finally, academics could complete our empirical contribution by overcoming the limitations of our sample, i.e., using a data set that fully captures firms' quality and/or expands over several years. Future contributions could also shed additional light on the market failure represented by discouraged borrowers by comparing them with non-applicants.

\footnotetext{
${ }^{1}$ Data provided by the Surveys on the Access to Finance of Enterprises carried out by the European Central Bank and the European Commission between 2005 and 2006.

${ }^{2}$ As a robustness check we define a new dummy variable, named multiple, which takes on the value one when the number of reasons for being discouraged ranges from two to five, and zero when firms report only one reason. Using this dependent variable, we estimate binary logistic regressions for the different specifications of our model. Results available upon request remain qualitative the same.

${ }^{3}$ We recognise that we do not have the ideal risk measure. For this reason, we use one year change in turnover, profit margin and cash flow as a best approximation. In light of our robustness checks, in our sample we strongly believe that more intensely discouraged borrowers are not riskier firms.

${ }^{4}$ Countries are categorized according to the 2003 GDP per capita and are then divided according to quartiles: low income (\$9343 or less): Czech Republic, Hungary, Estonia, Slovakia, Poland, Lithuania, and Latvia; and high income (\$31,135 or more): Luxembourg, Ireland, Denmark, Sweden, The Netherlands, Finland, and Austria.

${ }^{5}$ We recognize that one could wonder whether there are alternative measures which could be used. Unfortunately, on this we are limited by the data provided by the survey and we cannot attempt to define another measure for any other corporate characteristic or add additional firm-specific variables.

${ }^{6}$ In the interest of brevity, the tables do not show the industry dummies and their results are not discussed.

${ }^{7}$ In unreported results (available upon request), we test for over-dispersion and obtain that the dispersion parameter is zero, validating our decision of using a Poisson count model against a negative binomial count model (Cameron and Trevedi, 1990). In addition, since our dependent variable discouraged cannot take the value zero, we use a zero-truncated Poisson count model which analyses models that are left truncated on any value, not just zero. One could also raise the question of whether our model should be estimated using
} 
ordered logit models or count models. The use of ordered logit models requires that the actual values taken on by the dependent variable are irrelevant, except that larger values are assumed to correspond to "higher" outcomes. However, our dependent variable is a count variable, created counting (adding) each one of the reasons that would have encouraged firms to apply for financing. Therefore, the intensity of discouragement is measured in terms of counting, rather than ranking, and the values taken by the dependent variable are important. For example, borrower discouragement for firms with four reasons is twice as intense as it is for firms with two reasons.

${ }^{8}$ The survey does not establish a specific period that should be used as a reference to interpret the information collected regarding borrower discouragement. All we know is that it refers to financing decisions undertaken before 2005. To avoid reverse causality (or simultaneity), we opt for a conservative approach and measure the institutional environment variables in 2003, rather than in 2004. This also has an impact on the variable foreign, which we measure one year earlier using data from 2002. We do this because the presence of foreign banks might be determined by the development of the institutional environment.

${ }^{9}$ It is important to highlight that we only keep in our sample those SMEs which have not applied for a loan and give at least one of the reasons described in this section that would have encouraged them to resort to a loan.

${ }^{10}$ We should point out that in those models with multiplicative terms, the regression coefficient for the main effect only reflects conditional relationships and, therefore, it cannot be interpreted without taking into account the coefficient on the interaction term and the value of the moderator variable. This means that the effect of the variable foreign on borrower discouragement in regressions 2-4 depends on the interaction term and on the value of the moderator variables GDP per capita, enforcement and information respectively.

${ }^{11}$ Since two of our moderator variables are continuous, as a robustness check we build two dummy variables that equal one for firms in countries that are above the sample mean in terms of GDP per capita or the cost of debt enforcement mechanisms respectively and zero otherwise. We repeat the analyses in columns 2 and 3, Table 6, using these dummy variables instead of the variables GDP per capita and enforcement, and results (available upon request) remain qualitative the same.

${ }^{12}$ We should highlight two aspects of our analyses. First, our risk indicators present certain limitations when making comparisons in terms of borrower quality. For example, even good (bad) firms may have a bad (good) year, or said in another way, firms whose situation deteriorated during the previous year could be of better quality than those that have experienced some improvements. Second, since our sample is fully made up of discouraged borrowers, instead of comparing the quality between discouraged and nondiscouraged borrowers, we will be comparing the quality among discouraged borrowers subject to varying intensities of discouragement. 


\section{References}

Beck T, Demirgüç-Kunt A and Pería MSM (2011) Bank financing for SMEs: Evidence across countries and bank ownership types. Journal of Financial Services Research 39(1-2): 35-54.

Berger AN, Demirgüç-Kunt A, Levine R and Haubrich JG (2004) Concentration and competition: An evolution in the making. Journal of Money, Credit and Banking, 36(3): 433-451.

Berger AN, Klapper LF and Udell GF (2001) The ability of banks to lend to informationally opaque small businesses. Journal of Banking \& Finance 25(12): 2127-2167.

Berger AN, DeYoung R, Genay H and Udell GF (2000) Globalization of financial institutions: Evidence from cross-border banking performance. Brookings-Wharton Papers on Financial Services 3: 23-120.

Berger AN and Udell GF (2006) A more complete conceptual framework for SME finance. Journal of Banking \& Finance 30(11): 2945-2966.

Boustanifar H (2014) Information acquisition, foreign bank entry, and credit allocation. The Quarterly Review of Economics and Finance 54(3): 324-336.

Cameron AC and Trivedi PK (1990) Regression-based tests for overdispersion in the Poisson model. Journal of Econometrics 46(3): 347-364.

Canton E, Grilo I, Monteagudo J and Van der Zwan P (2013) Perceived credit constraints in the European Union. Small Business Economics 41(3): 701-715.

Chakravarty S and Xiang M (2013) The international evidence on discouraged small businesses. Journal of Empirical Finance 20: 63-82.

Claessens S and Laeven L (2004) What drives bank competition? Some international evidence. Journal of Money, Credit and Banking 36(3): 563-583. 
Claessens S and van Horen N (2014) Foreign banks: Trends and impact. Journal of Money, Credit and Banking 46(s1): 295-326.

Clarke GR, Cull R and Pería MSM (2006) Foreign bank participation and access to credit across firms in developing countries. Journal of Comparative Economics 34(4): 774-795.

Cole R and Sokolyk T (2016) Who needs credit and who gets credit? Evidence from the surveys of small business finances. Journal of Financial Stability 24: 40-60.

Cull R and Pería MSM (2008) Crises as catalysts for foreign bank activity in emerging markets. In: Robertson J. (eds) Power and Politics After Financial Crises. International Political Economy Series. Palgrave Macmillan, London: pp. 52-81.

Dell'Ariccia G and Marquez R (2004) Information and bank credit allocation. Journal of Financial Economics 72(1): 185-214.

Degryse H, Havrylchyk O, Jurzyk E and Kozak S (2012) Foreign bank entry, credit allocation and lending rates in emerging markets: Empirical evidence from Poland. Journal of Banking \& Finance 36(11): 2949-2959.

Detragiache E, Tressel T and Gupta P (2008) Foreign banks in poor countries: Theory and evidence. The Journal of Finance 63(5): 2123-2160.

Ferrando A and Mulier K (2015) The real effects of credit constraints: Evidence from discouraged borrowers in the Euro Area. Report, European Central Bank 1842.

Freel M, Carter S, Tagg S and Mason C (2012) The latent demand for bank debt: Characterizing discouraged borrowers. Small Business Economics 38(4): 399-418. Gormley TA (2011) Costly information, foreign entry, and credit access. American Finance Association 2008 New Orleans Meetings Paper.

Gormley TA (2014) Costly information, entry, and credit access. Journal of Economic Theory 154: 633-667. 
Grunert J and Norden L. (2012) Bargaining power and information in SME lending. Small Business Economics, 39(2): 401-417.

Hanedar EY, Broccardo E and Bazzana F (2014) Collateral requirements of SMEs: The evidence from less-developed countries. Journal of Banking \& Finance 38: 106121.

Jiménez G, Salas V and Saurina J (2009) Organizational distance and use of collateral for business loans. Journal of Banking \& Finance 33(2): 234-243.

Kon Y and Storey DJ (2003) A theory of discouraged borrowers. Small Business Economics 21(1): 37-49.

Leon F (2015) Does bank competition alleviate credit constraints in developing countries? Journal of Banking \& Finance 57: 130-142.

Levenson AR and Willard KL (2000) Do firms get the financing they want? Measuring credit rationing experienced by small businesses in the US. Small Business Economics 14(2): 83-94.

Mac an Bhaird C, Vidal JS and Lucey B (2016) Discouraged borrowers: Evidence for Eurozone SMEs. Journal of International Financial Markets, Institutions \& Money 44: 46-55.

Micco A, Panizza U and Yañez M (2004) Bank ownership and performance. IDB-RES Working Paper 518.

Mol-Gómez-Vázquez A, Hernández-Cánovas G and Koëter-Kant J (2018a) Legal and institutional determinants of factoring in SMEs: Empirical analysis across 25 European countries. Journal of Small Business Management 56(2): 312-329.

Mol-Gómez-Vázquez A, Hernández-Cánovas G and Koëter-Kant J (2018b) Bank market power and the intensity of borrower discouragement: Analysis of SMEs across developed and developing European countries. Small Business Economics 53(1): 211-225. 
Padoa-Schioppa T (2004) The evolving European financial landscape: Integration and regulation. Speech at the Colloquium organised by Groupe Caisse des Dépôts/KfW, Berlin. Available at:

https://www.ecb.europa.eu/press/key/date/2004/html/sp040322.en.html

Praet P (2016) The importance of a genuine banking union for monetary policy. Speech at the EMU Forum 2016, Vienna. Available at:

https://www.ecb.europa.eu/press/key/date/2016/html/sp161124.en.html

Xiang D, Worthington AC and Higgs H (2015) Discouraged finance seekers: An analysis of Australian small and medium-sized enterprises. International Small Business Journal 33(7): 687-707. 
Table 1. Overview of borrower discouragement and foreign ownership of banks by country in ascending order of foreign banks presence.

\begin{tabular}{|c|c|c|c|c|c|c|}
\hline Country & Foreign (\%) & Discouraged & $\begin{array}{l}\text { Multiple } \\
\text { discouragement } \\
\text { (\% of firms) }\end{array}$ & $\begin{array}{l}\text { Single } \\
\text { discouragement } \\
\text { (\% of firms) }\end{array}$ & $\begin{array}{l}\text { Discouraged } \\
\text { order }\end{array}$ & $\mathrm{N}$ \\
\hline \multicolumn{7}{|c|}{ Low presence of foreign banks } \\
\hline Germany & 4.21 & 2.71 & 78 & 22 & 18 & 200 \\
\hline France & 4.82 & 1.6019 & 39.34 & 60.66 & 11 & 211 \\
\hline The Netherlands & 6.06 & 1.2269 & 15.13 & 84.87 & 3 & 119 \\
\hline United Kingdom & 6.31 & 2.7742 & 75.48 & 24.52 & 21 & 155 \\
\hline Spain & 7.15 & 1.1275 & 7.35 & 92.65 & 1 & 204 \\
\hline Italy & 7.25 & 1.5182 & 30.45 & 69.55 & 10 & 220 \\
\hline Greece & 12.27 & 1.3333 & 25 & 75 & 7 & 72 \\
\hline Sweden & 18.94 & 1.2326 & 15.5 & 84.5 & 4 & 129 \\
\hline Denmark & 20.21 & 1.22 & 18 & 82 & 2 & 100 \\
\hline Portugal & 22.82 & 1.25 & 13.64 & 86.36 & 5 & 44 \\
\hline Austria & 23.93 & 1.4583 & 31.25 & 68.75 & 9 & 96 \\
\hline Slovenia & 26.44 & 2.3108 & 59.46 & 40.54 & 15 & 74 \\
\hline Mean Low & 10.60 & 1.70 & 36.45 & 63.55 & & \\
\hline \multicolumn{7}{|c|}{ High presence of foreign banks } \\
\hline Ireland & 30.42 & 1.2642 & 9.43 & 90.57 & 6 & 53 \\
\hline Belgium & 32.13 & 1.8051 & 44.92 & 55.08 & 12 & 118 \\
\hline Latvia & 39.14 & 2.7143 & 75.71 & 24.29 & 19 & 70 \\
\hline Malta & 48.26 & 2.75 & 72.5 & 27.5 & 20 & 40 \\
\hline Poland & 49.10 & 3.0468 & 89.47 & 10.53 & 24 & 171 \\
\hline Czech Republic & 58.98 & 2.7857 & 80.61 & 19.39 & 22 & 98 \\
\hline Hungary & 60.79 & 2.4095 & 65.71 & 34.29 & 16 & 105 \\
\hline Cyprus & 62.23 & 3.6667 & 95.24 & 4.76 & 25 & 42 \\
\hline Estonia & 68.87 & 2.3019 & 58.49 & 41.51 & 15 & 53 \\
\hline Slovakia & 81.51 & 2.6522 & 60.87 & 39.13 & 17 & 69 \\
\hline Finland & 85.83 & 1.3846 & 15.38 & 84.62 & 8 & 39 \\
\hline Luxembourg & 89.35 & 2.0448 & 55.22 & 44.78 & 13 & 67 \\
\hline Lithuania & 91.31 & 3 & 90.91 & 9.09 & 23 & 33 \\
\hline Mean High & 57.27 & 2.48 & 65.45 & 34.55 & & \\
\hline High-Low & $46.67 * * *$ & $0.78 * * *$ & $29.00 * * *$ & $-29.00 * * *$ & & \\
\hline
\end{tabular}

Descriptions and sources of all variables are reported in Table 2. The group low (high) presence of foreign banks includes those countries where the variable foreign is equal or lower (higher) than the sample mean. Single (multiple) discouragement is the percentage of firms that score (more than) one in the variable discouraged. Discouraged order refers to the ranking of countries in ascending order of the variable discouraged. High-Low presents the mean differences between firms in countries with high and low presence of foreign banks. *** denotes significance at the level of $1 \%$. 
Table 2. Variables, descriptions and data sources.

\begin{tabular}{|c|c|}
\hline Variable name & Description and source \\
\hline \multicolumn{2}{|l|}{ Dependent variable: } \\
\hline Discouraged $^{\mathrm{a}}$ & $\begin{array}{l}\text { Discouraged variable is an index that ranges from } 1 \text { to } 5 \text { where higher scores } \\
\text { indicate higher discouragement intensity. This index is constructed by } \\
\text { adding a " } 1 \text { " for every one of the following reasons which would have } \\
\text { encouraged firms to resort to a loan: (1) Lower interest rates; (2) Simpler } \\
\text { procedures for granting loans; (3) Less demanding on guarantee } \\
\text { requirements; (4) Shorter delays for granting loans; (5) Other reasons. }\end{array}$ \\
\hline \multicolumn{2}{|c|}{ Foreign bank presence: } \\
\hline Foreign ${ }^{\mathrm{b}}$ & $\begin{array}{l}\text { Foreign variable indicates the share of the assets of the banking system } \\
\text { which are foreign-owned in } 2002 \text {. }\end{array}$ \\
\hline \multicolumn{2}{|c|}{ Country-specific variables: } \\
\hline GDP per capita ${ }^{\mathrm{c}}$ & $\begin{array}{l}\text { GDP per capita is the natural logarithm of GDP per capita in current prices } \\
\text { in U.S. dollars divided by the population in } 2003 \text {. }\end{array}$ \\
\hline GDP growth ${ }^{c}$ & $\begin{array}{l}\text { Ratio of GDP growth expressed in current prices in U.S. dollars in the period } \\
\text { 2002-2003. }\end{array}$ \\
\hline Enforcement $^{\mathrm{d}}$ & $\begin{array}{l}\text { This variable measures the official costs of going through court procedures } \\
\text { for debt recovery divided by the debt value in } 2003 \text {. }\end{array}$ \\
\hline Recovery $^{\mathrm{d}}$ & $\begin{array}{l}\text { A measure of the efficiency of foreclosure or bankruptcy procedures in } \\
\text { 2003. It estimates how many cents on the dollar claimants, including } \\
\text { creditors, tax authorities, and employees recover from an insolvent firm. }\end{array}$ \\
\hline Information $^{\mathrm{d}}$ & $\begin{array}{l}\text { Dummy variable which that takes the value one if private credit bureaus } \\
\text { operate in the country in 2003, and zero otherwise. }\end{array}$ \\
\hline Herfindahl ${ }^{\mathrm{e}}$ & $\begin{array}{l}\text { The Herfindahl-Hirschman index refers to the concentration of the banking } \\
\text { sector in 2003. This index is obtained by adding the squares of the market } \\
\text { shares of all the credit institutions in the banking sector. It ranges from } 0 \text { to } \\
\text { 1, where higher values indicate a more concentrated banking system. }\end{array}$ \\
\hline \multicolumn{2}{|c|}{ Firm-specific variables: } \\
\hline Size $^{\mathrm{a}}$ & $\begin{array}{l}\text { Categorical variable which ranges from } 1 \text { for those firms with an annual } \\
\text { turnover below } 0.25 \text { million Euros in the last year, to } 7 \text { for those firms with } \\
\text { an annual turnover above } 5 \text { million Euros in the previous year. }\end{array}$ \\
\hline $\operatorname{Age}^{\mathrm{a}}$ & $\begin{array}{l}\text { Categorical variable which ranges from } 1 \text { for those firms that have been in } \\
\text { operation less than } 2 \text { years, to } 6 \text { for those firms that have been in operation } \\
\text { more than } 30 \text { years. }\end{array}$ \\
\hline Constraint $^{\mathrm{a}}$ & $\begin{array}{l}\text { This variable reflects the opinion of firms as to whether the projects cannot } \\
\text { be successfully concluded without a loan from the bank. The variable ranges } \\
\text { from } 1 \text { (totally disagree) to } 4 \text { (totally agree). }\end{array}$ \\
\hline Relation $^{\mathrm{a}}$ & $\begin{array}{l}\text { This variable gathers the opinion of the firm management on whether the } \\
\text { bank wants to take risks in lending to their company. This variable ranges } \\
\text { from } 1 \text { to } 4 \text {, denoting a better relationship with the bank when the variable } \\
\text { scores higher values. }\end{array}$ \\
\hline Industry dummies $^{\mathrm{a}}$ & $\begin{array}{l}\text { Each one of the seven industry dummy variables takes the value one if the } \\
\text { firm belongs to one of the following sectors: the extraction or production of } \\
\text { raw materials, construction or civil engineering, the production and } \\
\text { manufacturing of goods, trade and distribution, transport, business services } \\
\text { and, other services to consumers; and zero otherwise. }\end{array}$ \\
\hline Risk dummies $^{\mathrm{a}}$ & $\begin{array}{l}\text { Each one of the three dummy variables takes the value one if the situation } \\
\text { of the firm has deteriorated since the last year in terms of turnover, profit } \\
\text { margin and cash flow and zero otherwise. }\end{array}$ \\
\hline
\end{tabular}

Data sources:

a Survey on SMEs Access to Finance carried out by the European Commission between 2005 and 2006.

${ }^{b}$ Micco et al. (2004).

c United Nations Statistics Division.

${ }^{\mathrm{d}}$ Doing Business Indicators 2005, the World Bank.

e European Central Bank. 
Table 3. Overview of country-specific characteristics in ascending order of the level of GDP per capita.

\begin{tabular}{lllllll}
\hline Country & GDP per capita & GDP growth & Enforcement & Recovery & Information & Herfindahl \\
\hline Latvia & 4775 & 0.2083 & 0.11 & 0.85 & 0 & 0.1054 \\
Lithuania & 5424 & 0.3133 & 0.141 & 0.524 & 0 & 0.2071 \\
Poland & 5676 & 0.094 & 0.087 & 0.682 & 1 & 0.0754 \\
Slovakia & 6151 & 0.36 & 0.15 & 0.396 & 0 & 0.1191 \\
Estonia & 7282 & 0.3442 & 0.106 & 0.4 & 1 & 0.3943 \\
Hungary & 8243 & 0.2584 & 0.081 & 0.308 & 1 & 0.0783 \\
Czech Republic & 9343 & 0.2151 & 0.096 & 0.168 & 1 & 0.1187 \\
Malta & 12648 & 0.1917 & & & 1 & 0.158 \\
Slovenia & 14617 & 0.26 & 0.163 & 0.236 & 0 & 0.1496 \\
Portugal & 15472 & 0.224 & 0.175 & 0.699 & 1 & 0.1043 \\
Greece & 17356 & 0.3203 & 0.127 & 0.456 & 1 & 0.113 \\
Cyprus & 18256 & 0.2601 & & & 1 & 0.0946 \\
Spain & 21023 & 0.2877 & 0.141 & 0.834 & 1 & 0.0506 \\
Italy & 26172 & 0.236 & 0.176 & 0.435 & 1 & 0.024 \\
France & 28917 & 0.2342 & 0.117 & 0.466 & 0 & 0.0597 \\
Germany & 29384 & 0.2078 & 0.105 & 0.503 & 1 & 0.0173 \\
Belgium & 30251 & 0.2329 & 0.062 & 0.862 & 0 & 0.2063 \\
United Kingdom & 31134 & 0.1587 & 0.157 & 0.858 & 1 & 0.0347 \\
Austria & 31218 & 0.2235 & 0.098 & 0.725 & 1 & 0.0557 \\
Finland & 31522 & 0.215 & 0.072 & 0.902 & 1 & 0.242 \\
The Netherlands & 33356 & 0.2295 & 0.17 & 0.862 & 1 & 0.1744 \\
Sweden & 35221 & 0.254 & 0.059 & 0.732 & 1 & 0.076 \\
Denmark & 39488 & 0.2228 & 0.066 & 0.598 & 1 & 0.1114 \\
Ireland & 39631 & 0.2904 & 0.211 & 0.889 & 1 & 0.06 \\
Luxembourg & 65325 & 0.2913 & & & 1 & 0.038
\end{tabular}

Descriptions and sources of all variables are reported in Table 2. GDP per capita is reported without using natural logarithm. 
Table 4. Correlations.

\begin{tabular}{|c|c|c|c|c|c|c|}
\hline & Discouraged & Size & Age & Constraint & Relation & Foreign \\
\hline Size & $-0.0966 * * *$ & & & & & \\
\hline Age & $-0.0684 * * *$ & $0.1928 * * *$ & & & & \\
\hline Constraint & 0.0222 & $0.0564 * *$ & 0.0252 & & & \\
\hline Relation & $-0.0941^{* * *}$ & $0.0479 * *$ & $0.0407 *$ & $-0.0826 * * *$ & & \\
\hline Foreign & $0.2474 * * *$ & $-0.0673 * * *$ & $-0.1868 * * *$ & $-0.0910 * * *$ & $0.1117 * * *$ & \\
\hline GDP per capita & $-0.3530 * * *$ & $0.0904^{* * *}$ & $0.2790 * * *$ & 0.0189 & $-0.0897 * * *$ & $-0.7207 * * *$ \\
\hline GDP growth & $-0.2653 * * *$ & -0.0016 & $-0.1019 * * *$ & -0.0035 & $0.0922 * * *$ & $0.1212^{* * *}$ \\
\hline Enforcement & $-0.0819 * * *$ & -0.0233 & 0.0069 & $0.0392 *$ & $0.0873 * * *$ & $-0.3033^{* * *}$ \\
\hline Recovery & $-0.1508 * * *$ & -0.0171 & $0.0487 * *$ & -0.0209 & 0.0051 & $-0.2035 * * *$ \\
\hline Information & $-0.0432 *$ & -0.0147 & $-0.1891^{* * *}$ & -0.0238 & $-0.1186 * * *$ & $-0.1437 * * *$ \\
\hline \multirow[t]{2}{*}{ Herfindahl } & -0.0250 & -0.0265 & $-0.0416^{*}$ & $-0.0516 * *$ & $0.1058 * * *$ & $0.5588 * * *$ \\
\hline & GDP per capita & GDP growth & Enforcement & Recovery & Information & \\
\hline GDP growth & $0.0512 * *$ & & & & & \\
\hline Enforcement & $0.0883^{* * *}$ & $0.2162 * * *$ & & & & \\
\hline Recovery & $0.3048 * * *$ & $-0.2245^{* * *}$ & -0.0103 & & & \\
\hline Information & $0.1609 * * *$ & $-0.2068 * * *$ & $0.0519 * *$ & $0.1301^{* * *}$ & & \\
\hline Herfindahl & $-0.2509 * * *$ & $0.3092 * * *$ & $-0.2156 * * *$ & $0.0569 * * *$ & $-0.2482^{* * *}$ & \\
\hline
\end{tabular}


Table 5. Summary statistics.

\begin{tabular}{llllll}
\hline & Mean & Std. Dev. & Min. & Max. & $\mathrm{N}$ \\
\hline Discouraged & 1.9655 & 1.216 & 1 & 5 & 2056 \\
Size & 3.3662 & 2.1450 & 1 & 7 & 6 \\
Age & 4.1303 & 1.5497 & 1 & 4 & 2056 \\
Constraint & 2.4859 & 1.1436 & 1 & 4 & 2056 \\
Relation & 1.9917 & 1.0192 & 1 & 0.9131 & 2056 \\
Foreign & 0.2491 & 0.2395 & 0.0421 & 10.5874 & 2056 \\
GDP per capita & 9.8936 & 0.6576 & 8.4711 & 0.36 & 2056 \\
GDP growth & 0.2331 & 0.056 & 0.094 & 0.211 & 2056 \\
Enforcement & 0.1196 & 0.0399 & 0.059 & 0.902 & 2056 \\
Recovery & 0.6059 & 0.2107 & 0.168 & 1 & 2056 \\
Information & 0.7529 & 0.4314 & 0 & 0.3943 & 2056 \\
Herfindahl & 0.0905 & 0.0708 & 0.0173 & & \\
\hline Desciptions
\end{tabular}

Descriptions and sources of all variables are reported in Table 2. 
Table 6. Regressions analyses of the intensity of borrower discouragement and the presence of foreign banks.

\begin{tabular}{|c|c|c|c|c|c|c|}
\hline & Poisson (1) & Poisson (2) & Poisson (3) & Poisson (4) & Logistic (5) & Poisson (6) \\
\hline \multirow[t]{2}{*}{ Constant } & $5.8361 * * *$ & 1.2211 & $5.7102 * * *$ & $5.3870 * * *$ & 2.1506 & 2.0068 \\
\hline & $(0.8674)$ & $(1.6845)$ & $(0.8445)$ & $(0.9541)$ & $(1.4820)$ & $(1.9020)$ \\
\hline \multirow[t]{2}{*}{ Discouraged } & & & & & 0.0602 & \\
\hline & & & & & $(0.0460)$ & \\
\hline \multirow[t]{2}{*}{ Foreign } & $-2.0558 * * *$ & $8.4888 * *$ & $-3.4046 * * *$ & -0.1186 & -1.3796 & 3.9077 \\
\hline & $(0.6381)$ & (3.6253) & $(0.6894)$ & $(0.7339)$ & (1.0159) & $(4.0914)$ \\
\hline \multirow[t]{2}{*}{ Foreign*Foreign } & $3.0198^{* * *}$ & $1.5649 * *$ & $2.4588^{* * *}$ & $1.7241^{* * *}$ & 1.2034 & $1.7956 * *$ \\
\hline & $(0.5616)$ & $(0.7780)$ & $(0.5450)$ & $(0.5981)$ & (1.1048) & $(0.8715)$ \\
\hline \multirow[t]{2}{*}{ Foreign*GDP per capita } & & $-0.9620 * * *$ & & & & -0.5065 \\
\hline & & $(0.3259)$ & & & & $(0.3671)$ \\
\hline Foreign*Enforcement & & & $15.8292^{* * *}$ & & & \\
\hline \multirow[t]{2}{*}{ Foreign*Information } & & & & $-1.6819 * * *$ & & \\
\hline & & & & $(0.2979)$ & & \\
\hline \multicolumn{7}{|l|}{ Foreign*Developed } \\
\hline \multicolumn{7}{|l|}{ Country-specific variables: } \\
\hline \multirow[t]{2}{*}{ GDP per capita } & $-0.3067 * * *$ & 0.1347 & $-0.2491 * * *$ & $-0.2369 * * *$ & $-0.2983 * *$ & -0.0244 \\
\hline & $(0.0794)$ & $(0.1580)$ & $(0.0807)$ & $(0.0893)$ & $(0.1402)$ & $(0.1802)$ \\
\hline \multirow[t]{2}{*}{ GDP growth } & $-5.7964 * * *$ & $-5.9236 * * *$ & $-6.6508 * * *$ & $-7.3478 * * *$ & 0.8433 & $-4.6606 * * *$ \\
\hline & $(0.5262)$ & $(0.5522)$ & $(0.5936)$ & $(0.6571)$ & (1.1684) & $(0.6374)$ \\
\hline \multirow[t]{2}{*}{ Enforcement } & -0.0106 & 0.1721 & $-3.2667 * * *$ & -1.5389 & -0.8199 & 1.2634 \\
\hline & $(0.9414)$ & $(0.9310)$ & $(1.1791)$ & $(0.9931)$ & $(1.5555)$ & $(1.0421)$ \\
\hline \multirow[t]{2}{*}{ Recovery } & $-0.8477 * * *$ & $-0.8203^{* * *}$ & $-0.9217 * * *$ & $-1.3072^{* * *}$ & $-0.6207 * *$ & $-0.5520 * * *$ \\
\hline & $(0.1288)$ & $(0.1325)$ & $(0.1307)$ & $(0.1595)$ & $(0.2753)$ & $(0.1553)$ \\
\hline \multirow[t]{2}{*}{ Information } & $-0.2174 * * *$ & $-0.2049 * * *$ & -0.1002 & $0.2595^{* * *}$ & $0.2453^{*}$ & $-0.1359 *$ \\
\hline & $(0.0673)$ & $(0.0680)$ & $(0.0749)$ & $(0.0999)$ & $(0.1304)$ & $(0.0814)$ \\
\hline \multirow[t]{2}{*}{ Herfindahl } & -0.4050 & -0.2295 & 0.1287 & 0.5968 & $-1.9379 *$ & -0.5948 \\
\hline & $(0.6903)$ & $(0.6379)$ & $(0.6758)$ & $(0.7879)$ & (1.0183) & $(0.7457)$ \\
\hline \multicolumn{7}{|l|}{ Developed } \\
\hline \multicolumn{7}{|l|}{ Firm-specific variables: } \\
\hline \multirow{2}{*}{ Size } & $-0.0330 * * *$ & $-0.0325 * * *$ & $-0.0349 * * *$ & $-0.0346 * * *$ & -0.0380 & $-0.0276 * *$ \\
\hline & $(0.0105)$ & $(0.0105)$ & $(0.0104)$ & $(0.0104)$ & $(0.0244)$ & $(0.0122)$ \\
\hline \multirow[t]{2}{*}{ Age } & -0.0107 & -0.0049 & -0.0029 & 0.0076 & $0.1404^{* * *}$ & 0.0010 \\
\hline & $(0.0166)$ & $(0.0166)$ & $(0.0166)$ & $(0.0167)$ & (0.0369) & $(0.0186)$ \\
\hline \multirow[t]{2}{*}{ Constraint } & 0.0251 & 0.0225 & 0.0238 & 0.0240 & $0.1431^{* * *}$ & 0.0102 \\
\hline & (0.0189) & (0.0189) & $(0.0188)$ & $(0.0187)$ & $(0.0444)$ & $(0.0218)$ \\
\hline \multirow[t]{2}{*}{ Relation } & $-0.1041 * * *$ & $-0.1020 * * *$ & $-0.0999 * * *$ & $-0.0948 * * *$ & $-0.2286 * * *$ & $-0.0835 * * *$ \\
\hline & $(0.0234)$ & $(0.0234)$ & $(0.0234)$ & (0.0234) & (0.0528) & (0.0278) \\
\hline Industry effects & Yes & Yes & Yes & Yes & Yes & Yes \\
\hline Observations & 2056 & 2056 & 2056 & 2056 & 1956 & 1451 \\
\hline Pseudo $\mathrm{R}^{2}$ & 0.1249 & 0.1274 & 0.1279 & 0.1324 & 0.0410 & 0.1049 \\
\hline
\end{tabular}

The dependent variable is discouraged in Columns 1-4, profit margin in Column 5, and discouraged ranging from 1 to 4 without counting discouragement due to interest rates in Column 6 . All regressions include industry fixed effects. Definitions and sources are provided in Table $2 . *, * *, * * *$ denote significance at the levels of $10 \%, 5 \%$ and $1 \%$, respectively. Robust standards errors are in brackets. 
Table 7. Borrower discouragement and firm risk.

\begin{tabular}{|c|c|c|c|c|c|c|}
\hline & \multicolumn{2}{|c|}{ Turnover } & \multicolumn{2}{|c|}{ Profit margin } & \multicolumn{2}{|c|}{ Cash flow } \\
\hline & $\mathrm{N}$ & $\%$ & $\mathrm{~N}$ & $\%$ & $\mathrm{~N}$ & $\%$ \\
\hline Discouraged1 & 1351 & 21.84 & 1290 & 30 & 1299 & 19.25 \\
\hline Discouraged2 & 421 & 26.60 & 395 & 35.95 & 415 & 21.45 \\
\hline Discouraged3 & 298 & 25.84 & 275 & 37.82 & 285 & 25.61 \\
\hline Discouraged4 & 435 & 23.22 & 416 & 35.58 & 420 & 22.86 \\
\hline Discouraged5 & 55 & 29.09 & 53 & 41.51 & 53 & 18.87 \\
\hline & $F$ & Prob. & $F$ & Prob. & $\mathrm{F}$ & Prob. \\
\hline ANOVA & 1.56 & 0.1833 & 3.18 & $0.013 * *$ & 1.79 & 0.1285 \\
\hline
\end{tabular}

** denotes significance at the level of $5 \%$. 